\title{
Juvenile Delinquents' Learning Experiences in School within Prison: Narratives from the Malaysian Context
}

\author{
Vikneswari Nagamuthu, Narina A. Samah, Hadijah Jaffri, Lokman Mohd Tahir \\ School of Education, Faculty of Social Sciences and Humanities, Universiti Teknologi Malaysia (UTM), Johor, Malaysia
}

Received October 1, 2019; Revised November 22, 2019; Accepted December 3, 2019

Copyright@2019 by authors, all rights reserved. Authors agree that this article remains permanently open access under the terms of the Creative Commons Attribution License 4.0 International License

\begin{abstract}
Juvenile delinquents are those within the age of 10 to 18 years old who committed crimes or engaged in acts against the law. Those who are caught would be punished according to the law and serve their time either in correctional institution or prison depending on the severity of crime committed. Since they are considered as minor and supposed to be at school, while serving their time, they would have to attend school within the prison. Within the Malaysian context, these schools are referred to as Integrity Schools. This study aims to explore the learning experiences of juvenile delinquents in one of these schools. This qualitative study employed a narrative approach involving two students aged 18. Data was collected using semi-structured interviews, which were divided into two parts. Part A focused on the background information of the respondents while Part B consisted of questions meant to answer five research questions. Salient themes were derived from an inductive content analysis guided by the five research questions related to the juvenile delinquents' learning experiences while participating in educational program at the integrity school. The findings showed that both of the respondents expressed various learning experiences and there were a few similar experiences identified among both of them. Finally, the study suggested future researchers to include post-release experiences of juvenile delinquents in order to examine whether the benefits they hoped for upon release were genuinely attained.
\end{abstract}

Keywords Juvenile Delinquents, Learning Experience, Integrity School, Qualitative Study, Narrative Approach, Malaysian System

\section{Introduction}

Juvenile delinquent refers to a person aged below 21who participates and acts a crime such as rape, burglaries, property crime and so on has been sentenced to the Juvenile Court ${ }^{1}$.The phenomenon of juvenile delinquency among adolescents is increasingly alarming in Malaysia and leads them to be apprehended by law enforcers and juvenile delinquents end up in prison or correctional institution ${ }^{2}$. In general, for severe crimes committed, offenders would serve their time in prison, rather than correctional institution though. However, for offenders below 21 age, since they still hold the status as students at this age, they are regarded as juvenile delinquents and thus this later will raise the question of how juveniles who are serving a sentence obtain their educational right ${ }^{3}$. In this regard, with the introduction to correctional education as a part of the prisoner's rehabilitation, it provides a second chance for offenders to improve their chance to be reintegrated into the society and diminishes the rate of committing similar crime in the future ${ }^{4}$.

Based on statistics of juveniles' education level $^{5}$ in Malaysia as reported in 2013, it showed that out of the total 2831 juveniles, 161 or $5.69 \%$ aged 17 and under, 611 or $21.58 \%$ aged 17 - 18 years and 2059 or $72.73 \%$ aged $19-20$ years. In general, 2257 students or $79.72 \%$ went to pursue their study at the secondary school level. Moreover, as stated by The National Education Policy, Secondary Education is for students aged $12+$ to $17+$, therefore, this high rate indicates that they should be given an opportunity to continue schooling ${ }^{6 .}$

It is significant to establish in-school communities that encourage school surroundings because these elements increase students' engagement and participation in the academic activities at schools. Students who think their schools provide constructive quality, attentiveness and encourage the growth of learning environment will meet academic success preferably than their peers who drop out from the school ${ }^{7}$. Major offenders desire to become better individuals when released from detention and hope not to be detained in prison and even desire to become employed 
successfully $^{3}$. It was further stated that numerous studies displayed that the effective method to rehabilitate and reform behavior is through education.

\section{Background of Study}

Currently, there are only few countries in the world that provide educational facilities in prison and Malaysia is one of them. Malaysia's current history shows both the potential and difficulties of education in prison ${ }^{8}$. The success of the school within prison, known as Integrity Schools, was not only an outcome of school's decision in providing support for its students. In fact, despite all odds, students take the initiative to actively engage in classroom, determine to complete their assignments on time and work hard to achieve an excellent result ${ }^{9}$.

Even though there might be rooms for improvements in prison education, there are still vast potentials for exploration. Students often experienced the barriers to obtain knowledge in learning due to various factors existing in prison environment. Due to the personal educational experiences of offenders both prior to and during incarceration, they have negative thoughts related to schooling which is due to unpleasant experiences that contribute to the feelings of embarrassment and rage at becoming ineffective in a society whereby educational attainment is greatly valued ${ }^{8}$.

Most studies in the field of education in prison in Malaysia only focused on the effectiveness of the educational program $^{10,11}$ and recidivism ${ }^{10,12,13}$. However, only a few local studies carried out are regarding the challenges faced by students while engaging in the learning process in the prison $^{14,15}$. Moreover, general qualitative approach related to juvenile delinquents' educational experience in the school within the prison is limited in Malaysia. This study intended to narrow down the gaps in the literature by giving the opportunity to voice out unheard educational experiences but directly affect offenders at school within the prison or Integrity Schools. The following research questions were addressed:

1. What are the students' perceptions towards their prior education?

2. What motivates the students to participate in education program?

3. What are the students' perceptions regarding their studies in the prison?

4. What kind of challenges faced by the students while studying in prison?

5. What are the possible benefits of studying in prison to bring in their lives after released from detention?

\section{Methodology}

\subsection{Research Design}

This research used a qualitative methodology in order to explore the research questions stated, and to ensure a rich body of information and data was collected. Specifically, this qualitative study employed a narrative approach. As a distinct form of qualitative research, narrative approach usually emphasizes on studying an individual, gathering data through the collection of stories, reporting individual's experience, and discussing the meaning of those experiences for the individual ${ }^{16}$.

\subsection{Sampling Design}

The current research utilized purposive sampling to determine and select the information-rich cases for the most proper utilization of available resources. This requires identification and selection of individuals or groups of individuals who are experienced and well- informed with a phenomenon of interest ${ }^{17}$. Apart from knowledge and experience, importance was emphasized on the willingness and availability of the participants, and ability to express their experiences and perspectives in articulated, expressive, and reflective manner.

The sample size was limited to two juvenile delinquents who were currently undergoing educational program in Integrity School and willing to participate in this study in sharing their learning experiences. This study involved only two participants from a population of 91 juvenile delinquents from an Integrity School situated in the southern state of Peninsular Malaysia. established and maintained by the Department of Social Welfare.

\subsection{Data Collection Procedure}

Research data was collected by using semi-structured interviews with open-ended questions. Sub-questions were determined in the semi-structured interviews. Research using semi-structured interview is able to necessitate clear exploration of research questions as well as provide reliable, comparable qualitative data ${ }^{13}$. The open-ended questions in semi-structured interviews allow researchers to further their investigation in searching more detailed and elaborated information that is significant for respondents. In addition, this also provides the opportunity for identifying new ways of seeing and understanding the relevant issues which may not have previously been thought of as relevant to be researched.

In short, in this study the semi-structured interviews with open-ended questions were considered as one of the most appropriate types of interview because the interviews lead to narration of experiences in story-telling form by the respondents. Before the commencement of the interview session, the respondents briefed about the purpose of the research and the ethical principles such as confidentiality, anonymity, and right of withdrawal at any time during the interview sessions. The briefing helped the respondents to understand the interviewing process and minimize any discomfort that they might experience while being 
interviewed. All of the interview sessions were audiotaped and written notes were taken during interview sessions with respondents' permission.

\subsection{Method of Data Analysis}

The study employed inductive content analysis approach to analyze the data. As the name indicated, the inductive content analysis depended on inductive reasoning, in which themes were derived from the raw data through repeated examinations and comparisons. There are five steps that should be considered in inductive content analysis, which are, (1) open coding, (2) axial coding (3) creating themes, and (4) report findings of the study ${ }^{19}$. Therefore, the inductive content analysis was commenced by organizing the raw data by transcribing and typing verbatim transcripts, and following by close readings of the data. Data was analyzed by identifying open coding and axial coding. In the open coding column, the main parts of the responses of the participants were highlighted which answered the questions $^{20}$. From the open coding specific responses that were derived and presented in axial coding column in which they contained axial coding to create description for themes ${ }^{20}$. Finally, presented were the findings based on the interpretation of the data.

\subsection{Reliability and Validity}

In order to strengthen the reliability and validity of qualitative studies as well as balance bias issues that may occur in data collection or while analysing qualitative data ${ }^{21}$, credibility, transferability, and dependability were used.

\subsection{Ethics Approval}

Informed consent was obtained by registering and submitting application form to conduct research through MyResearch, an online application system of Department of Social Welfare, Malaysia. As a part of the regulation to conduct research involving juvenile delinquents at a prison integrity school, the report was submitted to the Department of Social Welfare upon the completion of the research. Confidentiality was applied by securing respondents' identity through the use of pseudonyms assigned for the research participants. In addition, the respondents explained their rights to participate or withdraw prior to data collection i.e. the interview sessions.

\section{Findings}

This section highlights the common, dominant and frequent themes raised by the respondents during their interview sessions. Data gathered from the interviews was analyzed and interpreted which was derived from two $(n=2)$ respondents. The background information of the respondents was presented first in order to underpin the potential transferability of the research findings.

\subsection{Background Information of the Respondents}

Table 1 shows the background information of the respondents. Both respondents were 18 years old when this study was conducted. Both were female and identified themselves as Malay. The highest level of education of both respondents was Malaysian Certificate of Education or Sijil Pelajaran Malaysia (SPM). The type of educational program that was currently participated by both respondents is vocational program. Respondent 1 indicated that she had experienced health problems or involved in substance abuse previously whereas Respondent 2 did not have any health problems nor involved in substance abuse before.

Table 1. Background information of the respondents

\begin{tabular}{|c|c|c|c|c|c|c|}
\hline Name & Age & Gender & Race & Highest level of education & $\begin{array}{c}\text { Types of } \\
\text { educational } \\
\text { program }\end{array}$ & $\begin{array}{c}\text { Health } \\
\text { problems or } \\
\text { substance } \\
\text { abuse }\end{array}$ \\
\hline Respondent 1 & 18 & Female & Malay & $\begin{array}{c}\text { Malaysian Certificate of Education } \\
\text { (Sijil Pelajaran Malaysia) }\end{array}$ & Vocational & Yes \\
\hline Respondent 2 & 18 & Female & Malay & $\begin{array}{c}\text { Malaysian Certificate of Education } \\
\text { (Sijil Pelajaran Malaysia) }\end{array}$ & Vocational & No \\
\hline
\end{tabular}




\subsection{Analysis of Interview Data}

The following section highlights the themes that are derived from the interview data. Each research question has several interview questions and therefore, the themes are displayed according to each of the interview questions. Both respondents are assigned and identified with pseudonym, namely R1 for Respondent 1 and R2 for Respondent 2 to present their responses from the verbatim transcript.

\section{Research Question 1: What are the students'perceptions towards their prior education?}

Table 2 summarizes the main themes derived from responses of the respondents regarding their educational background, relationship with teachers and authority figures, and peers as well as their perceptions on the influence of the relationship they had and prior academic achievement. Three interview questions were asked and seven themes were emerged from Research Question 1. Responses from Question 1 displayed that school mobility occurred from kindergarten until they discontinued their study in secondary school prior to detainment. They stated one common reason of school mobility which was following their family to move to different areas. Their answers mainly illustrated their experiences while attending primary and secondary schools. They elaborated how frequent change of schools affected their academic performance specifically how it interfered their learning due to their family move to a new place. They lamented how transition to the new environment made them face different sets of difficulties which they had to cope and it took longer time for them to adapt to new surroundings. They also had to catch up with the syllabuses which might have been covered in their new school. In addition, they also had to adapt to the pace of teaching and learning activities which might be different from their previous school. This resonates with what Respondent 1 had experienced
"I felt difficult to study because change schools...new school... new teachers, there is things that I did not learnt in old school, will already been taught in new school. Sometimes I will be thinking what the teacher is teaching because I just came into the class"

However, both respondents did not report any extreme behavior of not completing school assignments. Respondent 1 stated that her own attitude and inability to comprehend the content of the subject as the reasons for not completing schoolwork or homework. Respondent 1 further explained that

"Some school work is really difficult to do. Like Mathematics right, I don't know how to do it so I won't do it."

In this regard, her performance in learning was reported through reviewing her academic achievements and attitude in the classroom.

Interview about question 2 explores the relationship between the students and their teachers and school authority figures and how the relationship has an impact on the students' academic performance. Losing concentration in learning by displaying behavior of being inactive in class concerns the teachers. In accordance to this, the teachers displayed their concern by encouraging the student to involve in the various learning activities. It can be seen that the respondent identified herself as a quiet student and less engaging in classroom activities but still expected the teacher to pay attention to her learning.

In interview of question 3, respondents expressed that they tended to befriend with older students whom they considered as mature, reliable and with thoughtful ideas, which would help them in their learning. Peers' willingness to assist them in teaching using simple, straight-forward method and also giving tips and tricks to study has helped them to learn better.

Table 2. Themes emerged from interview questions in research question 1

\begin{tabular}{|c|c|}
\hline Interview Question & Themes \\
\hline \multirow{2}{*}{$\begin{array}{c}\text { Question 1: Share about your educational background from } \\
\text { kindergarten up to the highest level that ever learn before you } \\
\text { enter into this school? }\end{array}$} & Frequent school changes affect student academic achievement \\
\cline { 2 - 2 } & Failure in submitting school assignments \\
\cline { 2 - 2 } $\begin{array}{c}\text { Question 2: Share with me your relationship with teachers and } \\
\text { school authority figures and how it influences your academic } \\
\text { performance? }\end{array}$ & Teachers' concern towards student's academic progression \\
\cline { 2 - 2 } & Teachers' lack of attention on student ability in learning \\
\hline Question 3: Share with me / describe your relationship with the \\
friends and how it influences your academic performance?
\end{tabular}


Table 3. Themes emerged from interview questions in research question 2

\begin{tabular}{|c|c|}
\hline Interview Question & Themes \\
\hline \multirow{4}{*}{$\begin{array}{c}\text { Question 1: What is the reason you chose to participate in } \\
\text { the educational program? }\end{array}$} & To get a job after release \\
\cline { 2 - 2 } & Learning to acquire training certificate \\
\cline { 2 - 2 } & Education and training available at low-cost \\
\cline { 2 - 2 } & Learning to attain a specified objective \\
\cline { 2 - 2 } & Participate to do something enjoyable \\
\cline { 2 - 2 } & Passing the time effectively \\
\hline
\end{tabular}

Research Question 2: What motivate the student to participate in educational program?

Table 3 summarizes the main themes derived from responses of the respondents regarding the reasons they chose to participate in vocational program. Six themes emerged in Research Question 2. Respondent 1 stated her aim to get employed as motivation for her to learn new skills through vocational program provided by the school. The respondent also considered the program availability at her place of residence. Besides that, she also expressed several reasons that motivate her to participate in the vocational program. One of the reasons is she not only can obtain certification but also learn skills like sewing that are beneficial to her to get employed after serving her time in prison. In this case, she believes that she can be self-sufficient in getting herself employed.

Another reason is the program that Integrity School provides is perceived as comprehensive and such training might be costly elsewhere. Respondent 1 specifically said Integrity School helps her to attain several goals in life. Respondent 2 retrospectively elaborated her motive to participate in the educational program provided at the school.

"My time in here won't go wasted after I complete my academic program. Actually, I don't like tailoring but I would not be wasting my life for another one month. I will get released next month so I feel instead of not doing anything, I can actually learn something here"

Respondent 2 also reported that she feels motivated to engage in enjoyable various activities while studying in Integrity School and this reason drives her to actively participate in the educational program it offered. She also wishes to use her time in prison constructively.
Research Question 3: What are the students' perceptions regarding their studies in the prison school?

Table 4 summarizes the main themes derived from responses of the respondents regarding the students' current participation and learning experience in educational program. There are two questions asked and four themes emerged in Research Question 3. When asked to describe their feelings about the school environment and the facilities available in the school and its influence on their learning - Question 1, both respondents stated they are satisfied with the sufficient facilities and activities provided in the school. Respondent 2 elaborated in detail

"In the term of education, sport ... we have everything here. This school gives me a second chance to study ... continue my academic, gives me a chance to participate in sports ... all sort of things. It helps me to become a disciplined student ... first, be punctual in sports practice and complete my class work. We have a theory and practical so I need to finish my sewing within certain time before moving to next stage. Second, discipline myself by marching. I'm a leader of marching band, then I can also participate in dance, Kompang"

However, Respondent 1 lamented that the environment of her dormitory creates unpleasant atmosphere. Both of the respondents shared similar discontented view on the limitation for visiting hours by their family members. In Question 2 - relationship with peers while studying, Respondent 2 shares that she seeks for peers' assistance to improve her learning. She decides to befriend and surround herself with smarter students as a strategy to learn effectively. 
Table 4. Themes emerged from interview questions in research question 3

\begin{tabular}{|c|c|}
\hline Interview Question & Themes \\
\hline $\begin{array}{c}\text { Question 1: Share/ describe your feelings about the school } \\
\text { environment and the facilities available in this school and its influence } \\
\text { on your learning? }\end{array}$ & Various facilities and activities \\
\cline { 2 - 2 } & Unpleasant environment \\
\hline $\begin{array}{c}\text { Question 2: Share/ describe about your relationship with the students/ } \\
\text { peers while studying? }\end{array}$ & Limited visiting hours \\
\hline
\end{tabular}

Table 5. Themes emerged from interview questions in research question 4

\begin{tabular}{|c|c|}
\hline Interview Question & Themes \\
\hline \multirow{3}{*}{$\begin{array}{l}\text { Question 1: Share with me your experience with the school } \\
\text { environment that does not help/ prevent from learning and } \\
\text { achieving in school. }\end{array}$} & Limited social interaction \\
\hline & Unpleasant atmosphere disrupt learning \\
\hline & Distracting school schedule \\
\hline \multirow{2}{*}{$\begin{array}{l}\text { Question 2: Share with me your experience with the teachers that } \\
\text { do not help/ prevent from learning and achieving in school. }\end{array}$} & Negative attitude of the teacher towards the student \\
\hline & Insufficient number of teachers available \\
\hline $\begin{array}{l}\text { Question 3: Share with me your experience with the authority } \\
\text { that does not help/ prevent from learning and achieving in school. }\end{array}$ & Receive unfair treatment from authority towards the student \\
\hline
\end{tabular}

Research Question 4: What kind of challenges faced by students while studying in prison?

Table 5 summarizes the main themes derived from responses of the respondents regarding difficulties faced by the students in the term of school environment, the available facilities and how prison condition affects their learning. There are three questions asked and six themes emerged in Research Question 4. In Question 1, Respondent 1 emphasizes social interaction that she perceived has been restrained for students studying in prison school. She reported the school environment which is situated in a prison created a confined space by limiting students from interacting with friends and family freely. Respondent 1 also lamented that the school environment within school also creates an unpleasant atmosphere which interferes with her learning. She struggles to focus on her learning due to various disturbances mainly caused by other students and offenders. The respondent stated that she feels stressful by one of the school rules which emphasizes on roll call during teaching and learning period specifically as well as punishment which would be given to all of them even though they are not the perpetrators. She lamented that

"If one makes mistakes, everyone will get punishment at once ... so for me, it's very challenging. They like to mess around ... until get punished. They are quite stubborn people so everyone will get punishment because of them"

In Question 2, Respondent 1 felt that the teachers have negative attitude towards her involvement in other activities apart from sewing classes. Respondent 2 brought up the issue of lack of teachers' availability in the school. In Question 3, both respondents shared a similar experience where they received unfair treatment from prison school authority. The school authority plays little roles in student's education because they focus more on student' behavior management and rehabilitation.

Research Question 5: What are the possible benefits studying in prison to bring in their lives after released from detention?

Table 6 summarizes the main themes derived from responses of the respondents regarding benefits the student received during their participation in the educational program or the benefits that they hope to attain after being released from detention. There are two questions asked and five themes emerged in Research Question 5. In Question 1, Respondent 1 and Respondent 2 stated in the interview session that the school helps to improve their educational performance by developing self-discipline. Respondent 1 felt the school helps to improve her educational performance by associating it with the skill certification that she would receive when she completes the vocational program.

In Question 2, Respondent 1 shared about her aim of not repeating the offence she previously committed by appropriately matching re-offending thought with learning religion. Respondent 2 correlated her self-confidence with the types of activities and achievement she attains while participating in several activities while Respondent 1 believes that she has benefitted a lot throughout her involvement in the sewing program which helps to increase her employability skills. Respondent 2 reflectively stated that

"Before this, I wasn't confident enough. But after I came here, I learn to believe myself. When I was outside, I always said I can't do anything. I did not expect that I will get the opportunity to represent sports at regional and state level. So, I think it just my own words have been haunting me that I can't do anything but in reality, I could achieve something." 
Table 6. Themes emerged from interview questions in research question 5

\begin{tabular}{|c|c|}
\hline Interview Question & Themes \\
\hline $\begin{array}{c}\text { Question 1: Do you feel this school helps to improve your } \\
\text { educational performance? Explain why. }\end{array}$ & Develop self-discipline \\
\cline { 2 - 2 } $\begin{array}{c}\text { Question 2: Tell me about the benefits that you believe you } \\
\text { received in this school throughout your involvement in the } \\
\text { educational program. }\end{array}$ & Employability skills \\
\cline { 2 - 2 } & Reduce the thought of re-offending \\
\cline { 2 - 2 } & Increase self-confidence \\
\hline
\end{tabular}

\section{Discussion}

\section{Research Question 1: What are the students' perceptions towards their prior education?}

The juvenile delinquents' perceptions on their prior education influence their learning either positively or negatively. Their neutral perceptions of the influence of prior education would be associated with their experiences to face challenges due to frequent school changes. The feeling of low self-esteem and adjustment difficulties to new environment, friends and teachers are attributed to frequent change of schools that they perceive to interfere with their learning. A sense of insecurity affects them to confidently form new relationships as well as learn new things which can be related to female students' personal traits ${ }^{22}$ as having high tendency to be affected by internalizing responses such as depression and anxiety as compared to boys who are more likely to react externally. Shifting to new school might cause students to lose contact with their old friends and teachers and it also requires them to form new relationships at their new schools in order to survive in the new setting. Interaction with peers at school could also be affected while they are adjusting themselves to the new environment and facing various social challenges ${ }^{23}$. As expressed by both students in this study, gaps or repetitions in coursework and curricula, different academic standards and expectations pose challenges for them as they are required to repeat some of the content of certain subjects or syllabuses that they have already learned and mastered ${ }^{24}$.

In addition, another cause of students to perform poorly in their learning might be due to failure of submitting schoolwork which could be attributed to students' attitude and inability to comprehend the content of the subject list which inadvertently leads to hyperactivity, easily feeling bored and tired, shy and overly sensitive. The current findings reported that they are incapable of understanding the assigned homework. Another major reason of students who don't complete homework is they do not know how to do it and sometimes they are not able to comprehend the instructions of the assigned homework.

However, ineffective technique of learning paired with lack of focus might also lead to inconsistent academic performance. Paying attention might assist the learning process where it has substantial influence on immediate response of student and eventually leads to better academic outcomes $^{26 .}$ Both juvenile delinquents shared common perceptions regarding their teachers' influence on their academic performance. Teachers' concern towards their students learning shows that positive relationship was established among both parties. It is essential to have educators who concern for their students' strengths and needs, and who build and sustain an encouraging relationship with their students as well as maintain equality in providing opportunities to engage in the learning process ${ }^{27}$. Such chances make students feel comfortable to engage in classroom discussion and activities and this would inadvertently improve their academic skills. However, it is also important for the students to have a reciprocal relationship with their teachers.

Respondent 1 had difficulties to establish such relationship but expected the teacher to encourage and motivate passive students like her in the learning process. Almost every student has experienced moments where they feel difficult to express themselves in class due to shyness while doing activities at school. If a teacher has not dealt with the issue well, this might cause such students to decrease their level of self-confidence and usually, the students would withdraw from participating in any classroom activity ${ }^{28 .}$

Respondent 2 viewed positively the peer effects towards her learning. She has benefitted through peer interaction to increase her knowledge in learning especially through socializing with smarter peers. Students who are interested in academic issues are more likely to associate with peers who have the similar interest and aspiration and usually are perceived as smarter than them in order to help improve their academic performance and students who build positive peer group make more effort during learning and social activities $^{29}$

\section{Research Question 2: What motivates the student to participate in educational program?}

Generally, goal is the factor that affects the intrinsic and extrinsic motivation of a student. The factor of choices to participate caused by internal and external factors puts the goal as a drive for participation in the educational program among the juvenile delinquents in the school within the prison $^{30}$. Respondent 1 hopes to achieve specific objectives that she has set for herself by starting up a sewing business. She also has an alternative plan where she wants to get employed upon released related to the educational program that she undergoes at Integrity School. This is one of the 
reasons she prefers to participate in the vocational program and does not aim to pursue her studies in academic line.

In this case, having desire to improve one's occupational skills to be better prepared for the labor market after being released motivates them to participate in the educational program as exemplified by Respondent 1 . Motivation is a set of processes that energizes one's behavior and the aims lead the behavior to achieve a goal ${ }^{31}$. In this sense, a motivated person will make a positive choice based on the set goals and he or she is convinced that the action is meaningful to him or her and can satisfy his or her needs.

Intrinsic motivation is also important to sustain student engagement in vocational activities. Students who are intrinsically motivated to participate in a program are due the way they perceive the task as interesting and it is enjoyable to learn ${ }^{25 . .}$ Intrinsic motivation exists in the nexus between a person and a task in which the task is being perceived as interesting or in the other sense, the feeling of enjoyment and satisfaction a person gets while engaging in the task. Student's desire to alleviate or have a distraction from the prison environment drives the offender to participate in the educational program ${ }^{32}$ Even though escaping from other prison work and wanting to kill the time is not an ideal motivation to participate in learning, yet over a period of time offenders might become involved in prison education and indirectly start to develop the interest in the learning and conclude that it is something worth pursuing. The behavior of individuals who are motivated could be signified by the individual desire to overcome obstacles and be able to work hard to achieve their goal ${ }^{31}$.

As exemplified in this study, even though there are several obstacles faced by the Respondent 1 while learning such as having disruptive peers and unpleasant environment, she decides to participate and start to work hard by creating routines with the aim to gain knowledge and skill from learning theoretical and practical sewing techniques of various clothing designs that would enable her to pursue better work opportunities. She embraces this goal wholeheartedly. Respondent 1 is highly motivated by extrinsic motivation where she participates in learning with the hope to acquire certification and relieve her from financial burden. All behavior is motivated by rewards and intrinsically motivated activities appeared to be ones for which the reward has existed in the activity itself ${ }^{35}$.

Acquiring the certification is considered as a reward and testimony of the learning and training that they have undergone. Certification that is obtained also serves as the sign of completing the prison education and a source of pride and joy. Such certificate is highly valued for advancement in their future career. Providing education at lower cost by an organization naturally attracts low socio-economic status and families to encourage their children to participate in those educations programs $s^{35}$. A limited option available in the vocational program or the difficulty of the course does not hinder one of the respondents to pursue her education because the motivation to get a low-cost education in order to free from financial burden when she completes her studies emerged as a priority.

\section{Research Question 3: What are the students' perceptions regarding their studies in the prison school?}

Adequate and various facilities and activities for prison education help the offenders to learn effectively. Sufficient provision of facilities and active participation in various activities assist the student to acquire knowledge successfully ${ }^{36}$. The availability and genuine utilization of Integrity School facilities and activities influence positively students' personal development and academic achievement. Integrity School understudied in this study provides various non-educational activities and encourages the students to participate in it in order to develop self-concept, reform, and occupy their time outside classroom learning and training.

Although the school does it best in providing quality educational program, both of the juvenile delinquents have perceived some drawbacks. The feeling of unpleasant feeling towards the school environment stated by one of the respondents is specifically associated to the disruptive behavior of other students in the dormitory which creates unconducive setting for learning. Disruptive behavior has negative impacts in the classroom through various ways and it disrupts the smoothness of the learning process of other students $^{37}$. It was highlighted the difficulties associated with the negative attitude of inmates by involving in fights or bullying other inmates interfere with learning process as well as create a hostile atmosphere and develop a sense of insecurity for other inmates ${ }^{38}$.

Apart from that, although the prison school designed and required the students to obey the rules and regulations, the students viewed limited visiting hours by family members who develop feeling of detachment and sense of longing to gain love and affection from their family members. Students are still allowed to have physical contact with outsider but the rules are devised to limit the contact due to the security risk. The effect of strict security causes imprisonment to increase the feeling of loneliness and it may not in itself be conducive to the acquisition or strengthen social skills ${ }^{39}$.

Prison school culture is different from mainstream school culture but, the students' experiences or relationships with the other students or peers are quite similar. One of the respondents' attitudes towards surrounding herself with smarter students is regarded as an educational strategy to learn effectively that could be sustained and applied in future as well. The closest social interaction for an offender is with other offenders where eventually they will establish a decent relationship and assist each other in learning as well as give moral encouragement ${ }^{40}$. Similar to normal school, peer tutoring is essential since teachers are available for a certain and limited time, but peers can assist each other anytime by sharing ideas, giving-receiving feedback, and evaluating their own learning ${ }^{41}$.

Research Question 4: What kind of challenges are faced by students while studying in prison?

The challenges experienced while participating in 
learning interfere the student's learning as well as education attainment. Respondent 1 shared her experiences of limited social interaction with the individuals from outside of the school as a form of social education. As a matter of course, the offenders feel they are marginalized from the community and the experience of living behind the bars predominantly will aggravate their sense of detachment from the community as well as intensify their strains in coping or interacting with the community at large ${ }^{42}$. Restrained from interacting with outside world develops a negative attitude among the public and it was taken as a discouragement for the students to continue and give their full commitment in learning.

Unappealing environment in which education takes place can weaken the juvenile delinquents' motivation to learn. When educational activities take place together in an indistinct location where an unattractive atmosphere has already established, learning would pose extra challenges for the students within the prison school ${ }^{43}$. To be specific, offenders might perceive disruptive behavior of peers in the learning environment that creates an unpleasant environment for the student to learn. Disruptive behavior of the peers in the current study is seen coming from other students' exhibition of aggressive behavior, bullying other students, disturbing learning environment by talking frequently as well as being verbally and physically aggressive. Such behavior becomes a challenge where it creates chaotic and less conducive atmosphere for learning which more often than not would be perceived as harsh, ineffective and depressing process. Strict sentencing guidelines also emerged as a barrier, which disrupted learning process. Respondent 1 exemplified this when her time in learning was disrupted as students were instructed to assemble in order for prison school authority to take attendance or known as roll call.

While instructional time is commonly devoted to a particular subject, but in this study, it was found that it is a common practice to devote certain segment of the period with activities which have little or nothing to do with learning, such as roll call, briefing on disciplinary issues, and numerous interruptions by official announcements ${ }^{44}$. Therefore, with inadequate allocated time to teach or learn subjects, to some degree, it deteriorates students' education performance. Besides that, Respondent 1 experienced challenges in learning due to lack of support from teachers. Teachers in this current study demonstrated negative attitude towards the student's involvement in the other activities other than the vocational program by exhibiting verbal disapproval responses. Several studies put forward that teacher's criticism and strong disapproval negatively affect a student's behavior in the classroom and it is an ineffective method of maintaining student attentiveness in classroom. The current study found that the shortage of teaching staff for English Language subject caused Respondent 2 to be forced to learn English without proper guidance from any teacher. As a result, she failed to get good grades in her Malaysian Certificate of Education or

\section{Sijil Pelajaran Malaysia examination.}

Another important agent that plays a role in school within the prison is the prison school authority. Both of the respondents voiced out that they receive unfair treatment from prison authority. Prison authorities are always in contact with the juvenile delinquents and their attitude and behavior towards the students affect how successfully their complete education or training programs. In present study, even though, the respondents did not associate directly between the education and the treatment, and a feeling of dissatisfaction was developed by both respondents of this study. This might be due to the fact that even though the students display good behavior in the school, and receiving undeserved punishment from prison authority may lead the students to engage in and display anti-social behavior again.

Research Question 5: What are the possible benefits of studying in prison to bring in their lives after released from detention?

Both of the respondents believed that Integrity School helps them to improve their educational performance such as developing self-discipline and employability skills. There are also other benefits mentioned by both respondents throughout their involvement in the vocational program such as reducing the thought of re-offending, increasing their self-confidence, and enhancing employability skills. Behavior is formed based on the reinforcement given ${ }^{34}$ and when an individual promotes good behavior, he or she needs to be given continuous recognition and encouragement for such good behavior through reinforcement such as praise, gifts, tokens and other elements that encourage good behavior. Examples of positive reinforcement can be found in the responses given by Respondent 2. One of the reinforcements is in the form of allowing the student to watch movies because of good behavior exhibition or improvement in grades which encourages the student to retain her behavior and strive to excel well in upcoming exams.

Apart from that, the school helps to improve the student educational performance by associating it with the skill certification that they would receive upon completing the vocational program they underwent. The Integrity School located at the southern state of Peninsular Malaysia is one of the schools that offers their students to obtain Malaysian Skills Certificate (or known as Sijil Kemahiran Malaysia). The benefits of acquiring such skills certification are the certificate that is recognized by industry in Malaysia and also it would provide a better career path and encourage self-development comparable to career paths based on academic qualifications ${ }^{45}$. One of the respondents was well aware of the benefits she gets through participating in Malaysian Skills Certification training where she gets opportunities to explore the intricacies of business in terms of theoretical and practical aspects through training courses especially in entrepreneurship and business plan preparation courses. 
The rationale behind providing education in prison or Integrity School is to reduce the rate of delinquency and detainment. Respondent 1 expressed that religious education that is offered in the prison school helps to rehabilitate her in reforming her behavior and increasing her knowledge of Islamic teachings and this strengthens her belief of not repeating the offense she made before that landed her in prison. Even though religious education taught in Integrity School is considered as a non-formal education, it helps the offenders to identify issues such as anger management, and how to develop thinking skills among other skills to get integrated in society on release ${ }^{46}$. At its best, prison education helps the offenders to develop or build self-confidence. Self-esteem development is relying on a substantial degree of individual resources as well as situational condition, therefore the development of self-esteem highly varies between individuals ${ }^{47}$. When social conditions offer encouragement and possibilities to attain these basic needs, personal growth, liveliness and well-being could be enhanced ${ }^{48}$. The number of activities offered in the prison school increases one of the respondents' participation and achievement and this directly increases her confidence where she believes to have the capabilities to learn as well as perform good behaviors. Besides that, her self-confidence is also increased when teachers recognize the student's ability and allow them to demonstrate it. Apart from that, the provision of education and training brings benefits where the employment opportunity outlines how training and education need to be relevant to employment opportunities that exist in the location that the offender lives and is likely to be employed in.

\section{Conclusions}

The current study concludes that it is strenuous to impart implications for practice throughout the nation because the research findings are grounded on the stories of only two juvenile delinquents in the local authority even though the research findings reveal about various factors that influence the educational experience of the juvenile delinquents. Nevertheless, the results point out a guide for future studies, in addition, if homogenous findings have been demonstrated in other studies based on the implications which inflate the validity of the research study, essential recommendations for practice at a national level could be proposed then. Even though, the teachers' main duty is to provide education, an act of concern and unbiasedness towards the students, and constantly encourage them to do their best and show affection that would help students in deterring them to develop a sense of detachment from social interaction. The relevant organization ought to identify the current academic and vocational needs and upgrade or improvise the resources that help to improve learning and need to be relevant to the current education policy.

Several limitations are identified in the current study. The sample was limited to only two juvenile delinquents in one of the schools within prison in Malaysia. If the study was carried out involving other states' prison schools, different findings might be achieved. Secondly, in the current study only female respondents were involved and thus by employing male respondents in future research, different perceptions regarding their educational experience in the school within the prison could be attained. Thirdly, the researchers utilized purposive sampling and qualitative research approach therefore, the findings cannot be generalized. Finally, the researchers only used interview as a data collection method.

Other methods such as observation would help the researchers to gain empirical information regarding the students experience in the educational program. Future researchers are recommended to include post-release experience in order to examine whether the benefits they hope to get upon release are genuinely attained. In addition, respondents from different demographic backgrounds may be employed as well as different ages and races in order to explore relation between age or race and their educational experience. Most offenders desire to become better people so that they never have to return to prison. Many studies have shown that the best way to reform and improve behavior is through education even though students studying in prison face numerous challenges in their endeavor to amelioratethemselves. Our nation has a long way to go to ensure that prison education is successfully implemented in Malaysia and specific organization should take an initiative to resolve the challenges emerging in the prison education so that students could learn in conducive environment and successfully reintegrate into society.

\section{Source of Funding}

Research University Grant (RUG) of UTM (Tier 1: Ref. no. PY/2017/01815; Cost Center no. Q.J130000.2501.20H48

\section{Conflict of Interest}

Authors declare that there are no conflicts of interest.

\section{Ethical Clearance}

It was obtained from Department of Social Welfare, Malaysia.

\section{REFERENCES}

[1] Taib RM. Educational provision for young prisoners: To realize rights or to rehabilitate? Doctoral thesis. Brunel University, 2012.

[2] Rafedzi ERK, Abrizah A, Halida Y. Peranan perpustakaan 
penjara dalam pembentukan sahsiah pesalah juvana. Journal of Malaysian Librarians 2015; 9: 61-78.

[3] Van Heerden D. Books Behind Bars: Prisoners Education Trust [Online]. 2011 [Cited 2017 Oct]. Available from: URL: http://www.prisonerseducation.org.uk/index.php?id=396

[4] Abd Wahab Kassim. Juveniles on Remand: Trends and Practices in Malaysia [Online]. 2014 [Cited 2017 Sep]. Available from: URL: http://www.unafei.or.jp/english/pdf/R S_No68/No68_17PA_Kassim.pdf

[5] Malaysia Prison Department. (2013). Sistem Maklumat Pengurusan Pesalah: Statistik Tahap Pendidikan Penghuni. Kajang. JPM [Online]. 2013 [Cited 2017 Oct]. Available from: URL: http://www.prison.gov.my/portal/page/portal/bir u/berita?fac_next_page=htdcs/berita/ViewBerita.jsp?id=25

[6] Ministry of Education Malaysia. Dasar Pendidikan Kebangsaan [Online]. 2012 [Cited 2017 Oct]. Available from: URL:

https://www.moe.gov.my/index.php/my/dasar/dasarpendidik an kebangsaan

[7] O’Brennan LM, Bradshaw CP, Furlong MJ. Influence of classroom and school climate on teacher perceptions of student problem behavior. School Mental Health 2014; 6(2): 125-136.

[8] Rafedzi ERK, Abrizah A. Information needs of male juvenile delinquents: The needs to be met in a prison setting. Information Development 2014; n.d.

[9] Samuel R, Roaimah O. Female prisoners in Malaysia: An examination sociodemographic characteristics. Procedia Social and Behavioral Sciences 2012; 65: 505-510.

[10] Hadi Mohammed, Wan Azlinda WH. Reducing recidivism rates through vocational education and training. Procedia Social and Behavioral Sciences 2015; 204: 272-276.

[11] Saralah Devi M. Kesan intervensi psiko-positif terhadap tingkah laku agresif, kemurungan dan kecenderungan berubah penghuni muda penjara. Doctoral thesis, University of Utara Malaysia, 2013.

[12] Mohd Alif J, Siti Hajar AB, Jal Zabdi MY, Khairiyah MS, Noralina $\mathrm{O}$. The concept of recidivism: Ambiguity definition, measurement and practice. Akademika 2017; 87(3): 103-124.

[13] Siti Zabedah AJ, Sarimah I. Keberkesanan program pemulihan latihan kemahiran vokasional ke atas banduan-banduan sabitan di penjara sungai buloh, Selangor. Bachelor's thesis, Universiti Teknologi Malaysia, 2007.

[14] Darussalam B. Juvenil educations in Jabatan Penjara Malaysia: Policy, direction, implementation and challenges. Jurnal Hadhari 2013; 6(1): 87-104.

[15] Kamal Rafedzi, Ezza Rafedziawati, Abdullah, Abrizah, Zainal, Nur Khairunnisha. Kajian etnografi tingkah laku maklumat pesalah juvana lelaki di Malaysia. Informika: Jurnal Peradaban Informasi dan llmu 2013; 2: 55-68.

[16] Kim JH, Latta MM. Narrative inquiry: Seeking relations as modes of interaction. Journal of Educational Research 2009; 103(2): 69-71.

[17] Oppong SH. The problem of sampling in qualitative research. Asian Journal of Management Sciences and Education 2013; $1-9$.
[18] Blandford A. Semi-Structured Qualitative Studies [Online]. 2013 [Cited 2017 Dec]. Available from:URL: http://www.interactiondesign.org/encyclopedia/semistructure d_qualitative_uis.html

[19] Elo, S. \& Kyngas, H. The qualitative content analysis process. Journal ofAdvanced Nursing, 2008; 62(1): 107-115.

[20] Hsieh HF, Shannon S. Three approaches to qualitative content analysis. Qualitative Health Research 2005; 15:1277- 1288.

[21] Guba EG, Lincoln YS. Competing paradigms in qualitative research. In Denzin NK Lincoln, YS. Handbook of qualitative research. Thousand Oaks, CA: Sage, 1994.

[22] Barber BK, Olsen JA. Assessing the transitions to middle and high school. Journal of Adolescent Research 2004; 19: 3-30.

[23] Fantuzzo J, LeBoeuf WA, Chen C-C, Rouse HL, Culhane DP The unique and combined effects of homelessness and school mobility on the educational outcomes of young children. Educational Researcher 2012; 41: 393-402.

[24] Anderson S, Leventhal T, Dupéré V. Residential mobility and the family context: A developmental approach. Journal of Applied Developmental Psychology 2014; 35: 70-78.

[25] Mohamad MS, Norul Khairiah I, Nur Awanis AA, Nurul Huda, Siti Aisyah H. Kajian terhadap kesedaran pendidikan terhadap masyarakat orang asli. Persidangan Kebangsaan Pendidikan Luar Bandar 2009.Universiti Malaysia Sabah, 2009.

[26] Kruschke, J. Learning involves attention. Connectionist Models in Cognitive Psychology [Online]. 2000 [Cited 2018 Apr]. Available from: URL: http://www.indiana.edu/ krusch ke/articles/attn_chapter.pdf

[27] Allen J, Gregory A, Mikami A, Lun J, Hamre B, Pianta R. Observations of effective teacher-student interactions in secondary school classrooms: Predicting student achievement with the classroom assessment scoring system secondary. School Psychology Review 2013; 42(1): 76-98.

[28] James MG. Teaching behavioral modification to nonprofessionals. Journal of Applied Behavior Analysis 1972; 5(4): 517-521.

[29] Landau A. Peer groups and educational outcomes [Online]. 2002 [Cited 2018 Apr]. Available from: URL: htt!//inside.bard.edu/academics/specialproj/bullying/group2/ Alison.html

[30] Newby TJ. Classroom motivation: Strategies of first-year teachers. Journal of Educational Psychology 1991; 83(2): 195-200.

[31] McClelland DC. The achieving society. New York: The Free Press, 1961.

[32] Taffoni F, Tamilia E, Focaroli V, Formica D, Ricci L, Di Pino G, Baldassarre G, Mirolli M, Guglielmelli E, Keller F. Development of goal directed action selection guided by intrinsic motivations: An experiment with children. Experimental Brain Research 2014; 232(7): 2167-2177.

[33] Sheridan MJ, Steele-Dadzie TE. Structure of intellect and learning style of incarcerated youth assessment: A means to provide a continuum of educational service in juvenile justice. Journal of Correctional Education 2005; 56: 247-371.

[34] Skinner BF. Some thoughts about the future. Journal of the 
Experimental Analysis of Behavior 1989; 45: 229-235.

[35] Schumacker RE, Anderson DB, Anderson SL. Vocational and academic indicators of parole success. Journal of Correctional Education 1990; 41(1): 8-13.

[36] Crabbe MJ. Education for offenders in prison. Journal of Pedagogic Development 2016; 6(3): 1-7.

[37] Higgins J, Williams R, McLaughlin TF. The effect of a token economy employing instructional consequences for a third-grade student with learning disabilities: A data based case study. Education and Treatment of Children 2001; 24: 99-106.

[38] Snowling MJ, Adams J, Bowyer-Crane C, Tobin V. Levels of literacy among juvenile offenders: The incidence of specific reading difficulties. Criminal Behaviour and Mental Health 2000; 10: 229-241.

[39] Smiling R, Killacky J. Correctional education from the perspective of the prisoner student. Journal of Correctional Education 2008; 59(4): 301-320.

[40] Starkey H. Human rights, cosmopolitanism and utopias: implications for citizenship education. Cambridge Journal of Education 2012; 42(1): 21-35.

[41] Gendreau P, Ross R. Effectiveness of Correctional Treatment: Bibliotherapy for Cynics'. Crime and Delinquency 1979; 25: 563-589.

[42] Behan C. Learning to escape: Prison education, rehabilitation and the potential for transformation. Journal of Prison Education and Reentry 2014; 1(1): 20-31.

[43] Talton EL, Simpson RD. Relationships of attitude toward classroom environment with attitude toward and achievement in science among tenth grade biology students, University of Georgia. Journal of Research in Science Teaching 2004; 24(6): 507-525.

[44] Esperian JH. The effect of prison education programs on recidivism. Journal of Correctional Education (1974-) 2010; 61(4): 316-334.

[45] NurFatin. Technical and vocational education transformation in Malaysia: Shaping the future leaders. Journal of Education and Practice 2015; 6(22): 85-89.

[46] Johnson BR. Religious programs and recidivism among former inmates in prison fellowship programs: A long-term follow-up study. Justice Quarterly 2004; 21,: 329-354.

[47] Bukstel HL, Kilmann RP. Psychological effects of imprisonment on confined individuals. Psychological bulletin 1980; 88: 469-93.

[48] Deci EL, Ryan RM. Intrinsic motivation and self-determination in human behavior. New York: Plenum, 1985. 